vascular risk factors on coronary heart disease and mortality among middle aged diabetic men: a general population study. $B M \mp$ 1989;299:1127-31.

4 Ducimetière $\mathrm{P}$, Richard J-L, Claude J-R, Warnet J-M. Les cardiopathies ischemiques, incidence et facteurs de risque. L'erude prospective Parisienne. Paris: Editions INSERM, 1981:9-20.

5 Ducimetière $\mathrm{P}$, Eschwège E, Papoz L, Richard J-L, Claude J-R, Rosselin GE. Relationship of plasma insulin levels to the incidence of myocardial infarction and coronary heart disease mortality in a middle-aged population. Diabetologia 1980;19:205-10.

6 World Health Organisation Study Group. Diabetes mellitus. WHO Tech Rep Series 1985 ; No 727.

7 Ducimetière P, Richard J-L. The relationship between subsets of anthropometric upper versus lower body measurements and coronary heart disease risk in middle-aged men. The Paris prospective study I. Int $f$ Obesit 1989;13:111-22

8 Etienne G, Papin JP, Renault M. Une méthode simple de dosage du cholestérol par voie automatique. Ann Biol Clin 1963;21:851-9.

9 Claude JR, Corre F. Considérations pratiques sur le dosage semi-automatique des triglycérides sériques par fluoromérrie (méthode de Kiessler et Lederer) Comparison avec la méthode manuelle colorimétrique de Van Handel et Zilversmit. Ann Biol Clin 1968;26:451-4.

10 Méthodologie Technicon auto-analyser " $N$ " 2a, 2nd Ed. London: Technicon, 1963.

11 Antonis A Semi-automated method for the colorimetric determination of plasma free fatty acid. 9 Lipid Res 1965:6:307-12.

12 Rosselin GE, Assan R, Yalow RS, Berson SA. Separation of antibody bound and unbound peptide hormone labelled with iodine 131 by talcum powder and precipitated silica. Nature 1966;212:355-7.

13 Balkau B, Eschwège E, Fontbonne A, Claude J-R, Warnet J-M. Cardiovascular and alcohol-related deaths in abnormal glucose tolerant and diabetic subjects. Diabetologia 1992;35:39-44.

14 Papoz L, Warnet J-M, Pequignot G, Eschwège E, Claude J-R, Schwartz D. Alcohol consumption in a healthy population. Relationship to $\gamma$-glutamy transferase activity and mean corpuscular volume. FAMA 1981;245: 1748-51.

15 International Classification of Diseases. Manual for the international classification of diseases, injuries and causes of death. 8th revision. Geneva: WHO, 1968.

16 Cox DR. Regression models and life-tables (with discussion). foumal of the Royal Statist Society 1971;34B:187-220.

17 Eschwège E, Richard J-L, Thibult N, Ducimitière $\mathrm{P}$, Warnet J-M, Claude J-R, Rosselin GE. Coronary heart disease mortality in relation with diabetes, blood glucose and plasma insulin levels. The Paris prospective study; ten years later. Hormone Metab 1985;15:41-6.
18 Coppack SW, Doll HA, Pim B, Hockaday TDR. Intravenous glucose tolerance and mortality in non-insulin-dependent diabetes mellitus. Qf Med 1990;75:451-60.

19 Sasaki A, Horiuchi N, Hasegawa K, Uehara M. Mortality and causes of death in type 2 diabetic patients. A long-term follow-up study in Osaka district, Japan. Diabetes Res Clin Pract 1989;7:33-40.

20 Morrish NJ, Stevens LK, Head J, Fuller JH, Jarrett RJ, Keen H. A prospective study of mortality among middle-aged diabetic patients (the London cohort of the WHO multinational study of vascular disease in diabetics) II: associated risk factors. Diabetologia 1990;33:542-8.

21 Tountas C, Kofinis A, Kardoyiannis T, Pavlopoulos B, Karamanos B. Factors associated with the 10-year survival of a cohort of diaberic patients. Diabetologia 1987;330:589A.

22 Schmitz A, Vaeth M. Microalbuminuria and mortality in non-insulin dependent diabetes. Diabetes Metab 1988;14:193.

23 Knuiman MW, Welbom TA, Whittall DE. An analysis of excess mortality rates for persons with non-insulin-dependent diabetes mellitus in Western Australia using the Cox proportional hazards regression model. Am F Epidemiol 1992;135:638-48.

24 Barrett-Connor E, Wingard DL. Sex differential in ischaemic heart disease mortality in diabetics: a prospective population-based study. $\mathrm{Am}$ f Epidemiol 1983;118:489-96.

25 Jarrett RJ, Shipley MJ. Type 2 (non-insulin-dependent) diabetes mellitus and cardiovascular disease-putative association via common antecedents; further evidence from the Whitehall study. Diabetologia 1988;31:737-40.

26 Fitzgerald AP, Jarrett RJ. Are conventional risk factors for mortality relevant in type 2 diabetes? Diabetic Med 1991:8:475-80.

27 Ford ES, DeStefano F. Risk factors for mortality from all causes and from coronary heart disease among persons with diabetes. Am $₹$ Epidemio 1991;133:1220-30.

$28 \mathrm{Kohl} \mathrm{HW}$, Gordon NF, Villegas JA, Blair SN. Cardiorespiratory fitness, glycemic status, and mortality risk in men. Diabetes Care 1992;15:184-92.

29 Damsgaard EM, Froland A, Jorgensen OD, Mogensen CE. Eight to nine year mortality in known non-insulin dependent diabetics and controls. Kidney In 1992;41:731-5.

30 Jarrett J. Mortality in diabetes. Qf Med 1990;75:413-4.

31 Björntorp P. Obesity and diabetes. In: Alberti KGMM, Krall LP, eds. The diabetes annual: 5. Amsterdam: Elsevier, 1990:373-95.

32 Anderson P. Excess mortality associated with alcohol consumption. $B M F$ 1988;297:824-6.

(Accepted 21 May 1993)

\title{
Paternity by a seemingly infertile vasectomised man
}

\section{J A Thomson, P J Lincoln, Phyllis Mortimer}

\section{Department of \\ Haematology, London Hospital Medical College, London E1 2AD \\ J A Thomson, research assistant \\ P J Lincoln, reader in \\ haemogenetics}

Family Planning Service, Croydon Community Health, Croydon, Surrey Phyllis Mortimer, senior clinical medical officer

Correspondence to: Dr Lincoln.

BMF 1993;307:299-300
Vasectomy is a safe, reliable means of sterilisation, easily monitored by examination of semen at suitable intervals after operation. Failed operations, indicated by the presence of spermatozoa in the semen, are usually identified within a few months, although occasionally spermatozoa may reappear much later.

In later failures there can be either high levels of active spermatozoa (due to recanalisation of the vas deferens) or "non-significant" numbers of non-motile spermatozoa. Non-motile spermatozoa have been reported as having no clinical significance, ${ }^{1}$ and no confirmed associated pregnancies have been reported..$^{1-4}$

We report such a pregnancy. It was important from a clinical perspective, and for the benefit of the parties involved, that the true paternity of the child be confirmed.

\section{Case history}

The patient had a vasectomy in December 1987. Semen samples at 12 and 18 weeks after operation were clear of spermatozoa, and he was told that the vasectomy had been successful.

In 1990 his wife became pregnant. Repeated examinations of the husband's semen showed the presence of small numbers of non-motile spermatozoa, a pattern usually thought to indicate infertility. No motile spermatozoa were observed in five specimens.

A child was born in April 1991. It was decided to perform tests, including DNA profiling, to ascertain paternity. Blood samples from the patient, his wife, and the child underwent DNA profiling tests with six single locus DNA probes (Muc 7, MR24/1 (Amersham
International), YNH24, TBQ7, 3' $\alpha$ HVR (Promega), and MS43a (Cellmark Diagnostics)). Nineteen conventional protein polymorphisms were also analysed.

These tests provided no evidence that the patient was not the father of the child. Conventional test results produced a relative chance of paternity of about $94 \%$, and combination with the DNA profiling results, increased the chance of paternity to over $99.999 \%$. Such a figure is considered to offer virtual proof of paternity, provided a close relative of the named man is not a possible father. To eliminate this possibility, the patient's brother was tested and excluded from paternity on two out of five DNA tests utilised.

The wife has now had an intrauterine contraceptive device fitted. There are no immediate plans for a further operation on our patient.

\section{Comment}

This case shows fertilisation by a man deemed infertile by criteria normally accepted as defining successful vasectomy. This single case does not detract from the view that men with very few, non-motile spermatozoa after vasectomy are generally infertile,

Summary of semen examinations and other events

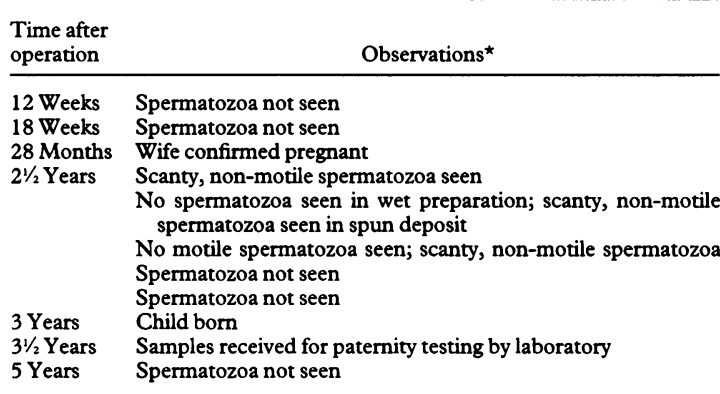

* Semen examinations were carried out on samples a maximum of two hour old and kept at room temperature. The whole film was scanned at $400 \times$ magnification by two members of staff. 
but it clearly demonstrates that this conclusion is not immutable.

Failed vasectomies are generally categorised early or late by the time lapse from operation to observed failure and by the nature and numbers of any spermatozoa seen. This case belongs to a small subset of failures where initial sperm counts were zero and only later (in this case after the pregnancy of the man's wife) were any spermatozoa identified. Even then the spermatozoa seen were very few and all non-motile, which would normally satisfy criteria for infertility. Alderman, when seeing such sperm characteristics, would "cautiously advise" that the vasectomy had been successful. ${ }^{4}$ This is supported by Edwards and Farlowe, who observed no associated pregnancies in 200 such failures.' Schmidt disagreed and would "find it difficult to believe that these patients [showing the presence of any spermatozoa of any kind] are totally safe."

The case also shows the value of DNA profiling in

establishing beyond doubt the paternity of a child in a situation where other factors strongly suggest a different explanation. It was important that a high relative chance of paternity was obtained in this case, and the high discriminating power of the DNA systems used ensured such a figure was obtained.

We acknowledge the help of Dr T J W Kelly, consultant clinical microbiologist at the Mayday Hospital, Croydon, for his work on the semen analysis.

1 Edwards IS, Farlowe JL. Non-motile sperms persisting after vasectomy: do they matter? $B M{ }^{f} 1979 ; \mathrm{i}: 87-8$.

2 Philp T, Guillebaud J, Budd D. Complications of vasectomy: review of 16000 patients. Br $\mathcal{G}$ Urol 1984;56:745-8.

Philp T, Guillebaud J, Budd D. Late failure of vasectomy after two documented analyses showing azospermic semen. $B M F$ 1984;289:77-9.

Alderman PA. The lurking sperm: a review of failures in 8879 vasectomies performed by one physician. $\mathscr{f} A M A$ 1988;259:3142-4.

5 Schmidt SS. Vasectomy. $7 A M A$ 1988;259:3176.

(Accepted 25 Fune 1993)

\section{General practitioners' contact with victims of suicide}

\section{Christopher A Vassilas, H Gethin Morgan}

Department of Mental Health, University of Bristol, Bristol BS2 8DZ Christopher A Vassilas, lecturer

H Gethin Morgan, professor

Correspondence to:

Dr C A Vassilas,

Department of Old Age

Psychiatry, West Suffolk

Hospital, Bury St Edmunds, Suffolk IP33 2QZ

$B M \mathcal{F} 1993 ; 307: 300-1$
Concern has recently been expressed over the increase in suicide rates in young adults in the United Kingdom, ${ }^{1}$ and the Health of the Nation has now set targets for health authorities to reduce rates of suicide. ${ }^{2}$ Although we know that up to $60 \%$ of people who commit suicide consult their general practitioners during the month before their death, ${ }^{34}$ up to date information is required on the way these patients present to health care professionals. We hypothesised that those with no history of psychiatric contact and younger suicide victims would have had fewer contacts with their general practitioner than those with a psychiatric history and older victims.

\section{Methods and results}

Over 20 months the Avon coroner's records were examined, and a note was made whenever a verdict of suicide, open, or accidental death was returned on an Avon resident. Summaries of all cases with open or accidental verdicts where the death was due to the same causes as those of suicide were presented to a panel of three consultant psychiatrists. If a majority of the panel thought that the death was a suicide that case was included in the study. The general practitioner responsible for the deceased was then interviewed. For each of the subjects general practitioners provided details of a matched control selected from the practice age-sex register as the next patient of the same sex born after the suicide victim.

A total of 83 suicide victims were identified. Sixty one open and accidental deaths were judged by the panel of psychiatrists to be suicides. In one case no information on a control was obtained. No data about contact with a general practitioner were available for five subjects. One hundred and thirty nine subjects $(96 \%)$ were thus included.

Of the 107 men and 32 women in the sample, 51 were aged under 35, 45 of them men. Eighteen (35\%) of the 51 people who committed suicide under 35 years of age and $49(56 \%)$ of the 88 who were aged 35 and over had ever had psychiatric contact $\left(\chi^{2} 4 \cdot 59, \mathrm{df}=1 ; \mathrm{p}=0.03\right)$. For all time periods up to a year those who were aged over 35 years were more likely to have consulted their general practitioners than those under 35 (see table).

Similarly, in the 28 days before death 34 of the 67 $(51 \%)$ of those with a history of psychiatric contact consulted their general practitioner compared with 18 of the $72(25 \%)$ who had no history of psychiatric contact $\left(\chi^{2} 8 \cdot 76, \mathrm{df}=1, \mathrm{p}=0.003\right)$.

Numbers of suicide victims (and percentages) consulting their general practitioners before death according to age

\begin{tabular}{lccc}
\hline $\begin{array}{l}\text { Time before } \\
\text { death } \\
\text { (weeks) }\end{array}$ & $\begin{array}{c}\text { No (\%) of patients } \\
\text { aged < 35 } \\
\text { consulting GP } \\
(\mathrm{n}=51)\end{array}$ & $\begin{array}{c}\text { No (\%) of patients } \\
\text { aged } \geqslant 35 \\
\text { consulting GP } \\
(\mathrm{n}=88)\end{array}$ & $\chi^{2}(\mathrm{df}=1)$ \\
\hline 1 & $2(4)$ & $23(26)$ & $9 \cdot 35, \mathrm{p}=0.002$ \\
4 & $10(20)$ & $42(48)$ & $9 \cdot 74, \mathrm{p}=0.002$ \\
13 & $21(41)$ & $58(66)$ & $7.07, \mathrm{p}=0.008$ \\
26 & $28(55)$ & $66(75)$ & $5.07, \mathrm{p}=0.02$ \\
52 & $32(63)$ & $69(78)$ & $3 \cdot 24, \mathrm{p}=0.07$ \\
\hline
\end{tabular}

In the four weeks before death there was no difference in the proportion of people under 35 consulting their general practitioner between suicides and controls (estimated odds ratio 1.67 (95\% confidence interval 0.55 to 5.58$), p=0.45$ ). However, the patients who committed suicide when aged over 35 were significantly more likely to have consulted their general practitioner than controls (estimated odds ratio 2.67 (95\% confidence interval 1.27 to $6 \cdot 25$ ), $\mathrm{p}=0.0003$ ).

\section{Comment}

In our study the proportion of all cases of suicide among people aged under $35(37 \%)$ was nearly four times higher than that found in Bristol 30 years ago. ${ }^{3}$ Although we have confirmed earlier findings that a substantial proportion of all suicide victims do see their general practitioner before their death (in this case $36 \%$ in the 4 weeks beforehand), this is clearly not the case for those aged under 35 . The reasons for this are not clear. Among the younger victims consultation patterns were no different from those of controls, and it may be that those aged under 35 do not feel it appropriate to discuss emotional or psychological problems with a doctor. There also appears to be a greater element of impulsiveness in these suicides, with fewer harbingers.

Educational campaigns aimed at teaching general practitioners to recognise and treat depressive illness have been suggested as ways of reducing suicide rates. ${ }^{5}$ For those aged under 35 other strategies must be found, as this group does not present to general 